\title{
Spatial Distribution Of Andaliman Potential Habitat (Zanthoxylum acanthopodium DC.) in Samosir Island, North Sumatera
}

Lasriama Siahaan $^{\mathrm{a}}$, Iwan Hilwan ${ }^{\mathrm{b}}$, Yudi Setiawan ${ }^{\mathrm{c}}$

aaraduate School, Bogor Agriculture University, Campus IPB Dramaga, Bogor 16680

${ }^{b}$ Department of Silviculture, Faculty of Forestry, Bogor Agriculture University, Campus IPB Darmaga, Bogor 16680

${ }^{\mathrm{c}}$ Center for Environmental Research, Research and Development Institute to the Community (PPLH-LPPM), Bogor Agriculture

University, Campus IPB Darmaga, Bogor 16680

\section{Article Info:}

Received: 24 - 08 - 2018

Accepted: 09 - 05 - 2019

\section{Keywords:}

Distribution patterns, samosir island, suitability spatial modeling, Zanthoxylum acanthopodium

\section{Corresponding Author:}

Lasriama Siahaan

Graduate School, Bogor

Agriculture University, Campus IPB Dramaga, Bogor;

Email: arilasunie@gmail.com

\begin{abstract}
Andaliman breeding and regeneration (Zanthoxylum acanthopodium DC.) in its natural habitat tends to be slow and difficult. The purpose of this research was to determine the distribution pattern, spatial character, and potential suitable habitat for andaliman growth with a suitability model approach in Samosir island, North Sumatera. Andaliman distribution pattern based on the calculation of the Standard Morisita Index (Ip) shows various patterns. There are three categories of distribution pattern, depends on the Standard Morisita Index The distribution patterns on each plot based on the calculation are: random (Location 1 - open area $(I p=$ $0.00)$ ), uniform (Location 2 - plantation forest (Ip $=-0.77)$; Location $3-$ open field $($ Ip $=-0.09))$, and clump (Location 4 - plantation forest $(\operatorname{Ip}=0.36))$. Analysis of habitat suitability for andaliman used spatial modelling with the Principal Component Analysis (PCA) approach. This method utilized ecological variables, i.e.: Bare Soil Index (BSI), slope, Digital Elevation Model (DEM), rainfall, Normalized Difference Moisture Index (NDMI), and Normalized Difference Vegetation Index (NDVI). The result is $69.8 \%$ of Samosir Island is suitable for andaliman, while $26.4 \%$ of it is considered as highly suitable habitat.
\end{abstract}

How to cite (CSE Style $8^{\text {th }}$ Edition):

Siahaan L, Hilwan I, Setiawan Y. 2019. Spatial distribution of Andaliman potential habitat (Zanthoxylum Acanthopodium Dc.) in Samosir Island, North Sumatera. JPSL 9(4): 861-871. http://dx.doi.org/10.29244/jps1.9.4.861-871.

\section{INTRODUCTION}

Andaliman (Zanthoxylum acanthopodium DC.) known as endemic Samosir island vegetation, in the form of shurbs, as the member of Rutaceae family with high economy value, anti microbial benefit, can be used as medicine and natural antioxidant (Wijaya 1999), natural preservative (Tensiska 2001), aromatic substance and appetite stimulant (Hasairin 1994). Andaliman lushly grows in subtropical climate in Himalayan mountain, and spread to eastern Pakistan, northern India, Nepal, Bhutan, China, Japan, Bangladesh, Laos, Myanmar, Thailand, Vietnam, Malayan Peninsula, and North Sumatra in Indonesia (Hartley 1966).

Economic value potential and content of chemical compound of andaliman is one of the trigger of its high market demand. In 2015 based on BKP2 Medan around $131987.8 \mathrm{~kg}$ andaliman in the form of seeds and 1 $960 \mathrm{~kg}$ of dried seeds being exported as domestic export commodity of North Sumatra province. High selling value of andaliman makes a lot of farmer do some cultivation ignoring the proper continuity and its habitat. People tend to recognize andaliman for its bitter and aromatic scent, but not its original vegetation. Andaliman 
often being used for daily and ceremonial dishes by people around Toba Lake, and currently become the one of the identity of local people around Toba Lake, known as Batak people.

The International Center for Underutilized Crops (ICUC) classifies plants based on their level of utilization in the community, among others: (1) Neglected and Underutilized Species (NUS), namely groups with untapped plant potential, and (2) Underutilized Plant Species (UPS) are groups with plant potential only limited to local commodities. Andaliman belongs to the category of UPS, plants with utilization and use only by the Batak community only. Andaliman in the Encyclopedia of life is referred to as Japanese pepper with an unreviewed status, while the Indian Biodiversity Portal mentions andaliman as Indonesian lemon pepper with status accepted name (Kokilavani and Narayanan 2018), as well as in the HKH conservation portal grouping the IUCN andaliman categories as N/A and CITES Appendix as N/A.

In Indonesia, andaliman does not include plant species that are protected under Government Regulation No. 7 of 1999. Although andaliman excluding rare plants, but this endemic plant is naturally difficult to germinate because the seed dormancy period varies. As a result farmers at the research location only rely on saplings that grow naturally in the forest. This becomes a critical point where andaliman in nature, if this situation continues, the longer the increasingly scarce availability of saplings andaliman.

\section{Purpose}

Knowledge about andaliman spatial distribution pattern and its relationship with habitat condition is one of the important steps towards planning conservation, mainly in the effort to reintroduce, restoration or recovery natural andaliman population. This idea is based on the hypothesis that natural andaliman distribution has some pattern which is related by its habitat characteristic.

Therefore, the purpose of this research is to obtain latest data about distribution characteristic and habitat condition of andaliman also to develop a relationship model between spatial distribution pattern and habitat characteristic in Samosir Island.

\section{METHOD}

\section{Research Location}

This research was done in Samosir Island (Ronggur Nihuta sub-district) in North Sumatera Province with the area of 64,418 ha. Geographically this location defined $2^{\circ} 36^{\prime} 08^{\prime \prime}$ NL and $98^{\circ} 48^{\prime} 18^{\prime \prime}$ EL. Samosir island is under the administration of Samosir district. There are 4 locations that are used as transect lines, where each transect line has $2-4$ plots. Coordinat of location 1 are $\mathrm{X}=98.8014$ and $\mathrm{Y}=2.6609$, location 2 are $\mathrm{X}=$ 98.9080 and $\mathrm{Y}=2.6506$, location 3 are $\mathrm{X}=98.8009$ and $\mathrm{Y}=2.6169$, and location 4 are $\mathrm{X}=98.7959$ and $\mathrm{Y}=$ 2.6165. Every andaliman found in the transect line is recorded with GPS.

\section{Data Collection}

For the preliminary data of the andaliman location, this study used to types of data: primary, interview with local merchants; and secondary data from literatures, which was held on September 2017 - March 2018. Further, transect lines were made in some locations based on those preliminary data.

Transect line conducted in four different locations (11 plots) along the track sized $10 \mathrm{~m}$ x $10 \mathrm{~m}$ using purposive random sampling method with determination criteria as follows: (the plot was made at the location where Andiman was found, (2) the plot was made in a location that was possible to be measured, (3) the selected plots had typical different land uses. Vegetation analysis was done by observation plot in level of understorey and seedlings, sapling level and pole level. Result from vegetation transect preserved to be herbarium and then identified in LIPI Bogor. A sampling plot with area of $10 \mathrm{~m} \times 10 \mathrm{~m}$ was used for poles level observation, a sampling plot with area of $5 \mathrm{~m} \times 5 \mathrm{~m}$ used for sapling level observation, and a sampling plot with area of $2 \mathrm{~m} \times 2 \mathrm{~m}$ used for understorey and seedlings level (Soerianegara and Indrawan 1998). 
Samosir Island data sources used for this research is the image of Landsat 8 path/row 128/58 and 128/59 date of aquisition 20 - 28 July 2017, Samosir Island Administration Map (BIG) 1:150000, DEM Map Samosir Island (USGS/Aster G DEM) and RBI maps Indonesia (RBI) then processed by using SPSS Statistics, ArcGis 10.3, and Erdas 9.1.

The presence of point data used in the preparation of the model as much as 153 points of presence. A total of $70 \%$ (77 point of presence) observational data are used as data for developing the model, while $30 \%$ (53 point of presence) used for model validation. Ecology variable used as estimator variables that influence andaliman functionally and structurally (Odum 1993; Hasan, 2012) were used in spatial suitability of andaliman habitat are vegetation factor (Normalization Difference Vegetation Index/NVDI), physical (elevation, slope, Bare Soil Index/BSI), micro climate (Normalized Difference Moisture Index/NDMI) and rainfall Samosir island for five years (2011-2015). Ecological variables as predictor can be seen in Table 1.

\section{Data Analysis}

The spatial pattern of andaliman is known by using the Morishita index (I $\delta$ ) which has been standardized (Jongjitvimol et al. 2005), namely:

$\mathrm{I} \delta=$ Morishita index

$$
\mathrm{I} \delta=\mathrm{nx} \frac{\sum \mathrm{x} 2-\sum \mathrm{x}}{\left(\sum \mathrm{x}\right) 2-\sum x}
$$

$\mathrm{n}=$ number of sampling plots

$\mathrm{Xi}=$ the number of individuals found in each plot.

If the value of Id $=0$ then the similarity of the community is low, while Id $=1$ then the similarity of the community is high / equal. While the distribution of andaliman patterns is shown by Mu and Mc's calculations, including:

$\mathrm{Mu}=$ Morisita Index for uniform patterns

$$
\begin{aligned}
& \mathrm{Mu}=\frac{\left(X^{2} 0.975-n+\sum x i\right)}{\left(\sum x i\right)-1} \\
& \mathrm{Mc}=\frac{\left(X^{2} 0.025-n+\sum x i\right)}{\left(\sum x i\right)-1}
\end{aligned}
$$

$X^{2} 0.975=$ Chi-square table value with $\mathrm{n}-1$ free degree and $97.5 \%$ confidence interval

Mc $=$ Morisita index for clustering patterns

$X^{2} 0.025=$ Chi-square table value with $\mathrm{n}-1$ free degree and $2.5 \%$ confidence interval

Morisita degree standards are calculated by the formula:

$$
\begin{array}{ccc}
\text { Ip } & =0.5+0.5\left(\frac{I d-M c}{n-M c}\right) ; \text { if } \text { Id } \geq \mathrm{Mc} \geq 1 \\
\text { Ip } & =0.5+\left(\frac{I d-1}{M c-1}\right) ; \text { if } \mathrm{Mc} \geq \mathrm{Id} \geq 1 \\
\text { Ip } & =-0.5+\left(\frac{I d-1}{M u-1}\right) ; \text { if } 1 \geq \mathrm{Id} \geq \mathrm{Mu} \\
\text { Ip } & =-0.5+0.5\left(\frac{I d-M u}{M u}\right) ; \text { if } 1 \geq \mathrm{Mu} \geq \mathrm{Id}
\end{array}
$$

Based on the Ip value, it can be concluded that the distribution pattern is uniform distribution if $\mathrm{Ip}<0$, random distribution, if Ip $=0$, and clump distribution if $\mathrm{Ip}>0$.

Factors that take effects to andaliman distribution can be analyzed by Principle Component Analysis/PCA. Analysis was done based on points of andaliman presence and estimator variable layer such as slope, BSI, DEM, rainfall, NDVI, dan NDMI. Some steps to get PCA value was: (1) create each (slope, BSI, DEM, rainfall, NDVI, dan NDMI); (2) extract values of each layers using tools value to point and then normalized to prevent a bias in each variable; (3) Variable value from normalizing result processed by using SPPS 16.0 with analyze in data reduction to get PCA value by using Keiser-Meyer-Olkin method. PCA value used as an expected 
number of suitability model; (4) a spatial analysis to choose factors to get overlay predictor, class, weighting and scoring.

Andaliman habitat suitability map was created with ArcGis 10.3 software, by combining all influencing estimator variable (Syartinilia and Tsuyuki 2008). Modelling result of habitat suitability category obtained by obtained pixel distribution map. Habitat suitability category of andaliman can be seen in Table 2.

Table 1. Ecological variables as predictor

\begin{tabular}{|c|c|c|c|c|c|c|}
\hline No & Variabel & Data & $\begin{array}{c}\text { Unit of } \\
\text { measureme } \\
\text { nt }\end{array}$ & $\begin{array}{l}\text { Data } \\
\text { scale }\end{array}$ & Data source & $\begin{array}{l}\text { Data extraction } \\
\text { method }\end{array}$ \\
\hline 1 & $\begin{array}{l}\text { Andaliman } \\
\text { presence } \\
\text { point }\end{array}$ & $\begin{array}{l}\text { Ordinate } \\
\text { point }\end{array}$ & & & $\begin{array}{l}\text { Field } \\
\text { observation }\end{array}$ & \\
\hline 2 & $\begin{array}{l}\text { (x1) } \\
\text { Altitude }\end{array}$ & $\begin{array}{l}\text { Physical } \\
\text { component }\end{array}$ & $\mathrm{m}$ asl & Ratio & $\begin{array}{l}\text { Altitude map } \\
\text { (DEM) }\end{array}$ & $\begin{array}{c}\text { Slope tophography } \\
\text { analysis }\end{array}$ \\
\hline 3 & (x2) Slope & $\begin{array}{l}\text { Physical } \\
\text { component }\end{array}$ & $\begin{array}{l}\text { Percentage } \\
(\%)\end{array}$ & Ratio & $\begin{array}{l}\text { Slope map } \\
\text { (DEM) }\end{array}$ & $\begin{array}{c}\text { Slope tophography } \\
\text { analysis }\end{array}$ \\
\hline 4 & (x3) NDVI & $\begin{array}{l}\text { Green } \\
\text { vegetation } \\
\text { index }\end{array}$ & & Ordinal & $\begin{array}{l}\text { Vegetation } \\
\text { index map } \\
\text { (NDVI) }\end{array}$ & $\frac{(N I R-R e d)}{(N I R+R e d)}$ \\
\hline 5 & (x4) Rainfall & $\begin{array}{l}\text { Physical } \\
\text { component }\end{array}$ & $\mathrm{mm} / \mathrm{year}$ & & $\begin{array}{l}\text { Rainfall in } \\
\text { Samosir }\end{array}$ & \\
\hline 6 & $\begin{array}{l}(\mathrm{x} 5) \\
\text { NDMI }\end{array}$ & Humidity & & Ratio & $\begin{array}{l}\text { Humidity index } \\
\text { map (NDMI) }\end{array}$ & $\frac{(N I R-S W I R)}{(N I R+S W I R)}$ \\
\hline 7 & (x6) BSI & $\begin{array}{l}\text { Soil } \\
\text { bareness }\end{array}$ & & Ratio & BSI Map & $\frac{(S W I R 1+R e d)-(l}{(S W I R 1+R e d)+(l}$ \\
\hline
\end{tabular}

Note $:$ NDVI $=$ Normalization Difference Vegetation Index, NDMI $=$ Normalized Difference Moisture Index , BSI $=$ Bare Soil Index, NIR $=$ Near Infra Red/Band 5, Red $=$ Band 4, SWIR $=$ Short-wave Infrared 1/band 6, Blue $=$ Band 2

Table 2 Habitat suitability category of andaliman.

\begin{tabular}{cll}
\hline No & \multicolumn{1}{c}{ Category } & \multicolumn{1}{c}{ Range } \\
\hline 1 & highly suitable & {$[$ Min- $($ Mean $-2 * \operatorname{Std}$ Dev $)]$} \\
2 & Suitable & {$[($ Mean $-2 * \operatorname{Std}$ Dev $)-($ Mean - Std Dev $)]$} \\
3 & Moderat suitable & {$[($ Mean - Std Dev $)-($ Mean + Std Dev $)]$} \\
4 & Poor suitable & {$[($ Mean + Std Dev $)-($ Mean $+2 *$ Std Dev $)]$} \\
5 & Unsuitable & {$[($ Mean $+2 *$ Std Dev $)-$ Max $]$} \\
\hline
\end{tabular}

Note: Min $=$ minimum value of PCA result, Mean $=$ mean value of PCA result, Std Dev $=$ Standard devition of PCA result.

\section{Habitat Suitability Model Validation}

Validation of the PCA model for andaliman land suitability is carried out using presence data by looking at the validation value of the model extrapolation results spatially. The validity of the model seen from the high percentage of the value of the data point of presence andaliman at high suitability for andaliman class. Model validation is useful to indicate whether the model is acceptable and can be extrapolated in other regions or not. If the validation value more than $80 \%$ of the match then the model is feasible. This tool combines all available information (significant environmental variables) into a map of conformity (Syartinilia and Tsuyuki 2008). 
Andaliman's habitat suitability model validation is done by presence data model extrapolation, in order to measure properness of formed model, by andaliman presence percentage in each suitability class. The proportion of model from compiled data with validating data is $70 \%$ : $30 \%$. Equation that used for model validation is:

$$
\text { Validation }=\frac{n}{N} \times 100 \%
$$

$\mathrm{n}=$ number of presence spot existed in particular suitability class

$\mathrm{N}=$ total number of presence spot based on observation.

\section{RESULTS AND DISCUSSION}

\section{Andaliman distribution pattern}

Andaliman grows in secondary forest, open field, with the temperature between $15-18{ }^{\circ} \mathrm{C}$, in $1,300 \mathrm{~m}$ asl altitude (Hartley 1966; Hasairin 1994; Yonzone and Rai 2016), a slight acidic soil condition in pH between $3.0-4.5$ and the best soil condition for cultivation is clay sand, reddish viscuous laterite (Yonzone and Rai 2016). Based on the distribution area, as subtropical vegetation, andaliman grows in plateau. Andaliman habitat in Samosir Island mostly are available on the side of open forest in pure clay soil, dusty clay with good drainage.

The result of this research shows that andaliman distribution pattern based on nearest distance between individual different for each observation location. The value of standard Morisita index (Ip) is 0.00 in location 1 which is fit with random distribution pattern. In location 2 (Ip = -0.77) and location 3 (Ip = -0.09) which is fit with uniform distribution pattern, but in the location $4(\mathrm{Ip}=0.364)$ fit with clump distribution. Aggregation or individual organisms grouping in between population are caused by reproduction process or social attraction. The results of this study support Hartley's (1966) and Odum's theories (1993) that state andaliman distribution in North Sumatera widely grouped in certain areas, but internal distribution of andaliman in Samosir island shows random, uniform and clump.

Several other factors that affect the spatial pattern of plants include: (1) Catasthropic (Leps and Kindlmann 1987) in Location 1, because they are fields that have been burned; (2) the shade of canopy cover that is sufficiently close will affect the plants that shelter under it (Leps and Kindlmann 1987), in this case location 2 is a plantation forest with a fairly close canopy cover; (3) location 3 is monoculture agriculture, where the dominant plant is andaliman so it has an almost uniform distance; and (4) location 4 is a plantation forest but is used as a patchy habitat area (Suzuki et al. 2005) for andaliman, and has been used for a long time (20 years).

Another reason based on a review of Morista index measurements by Bleher et al. (2002) with a simulation approach states that the index measuring Morisita on squared plots smaller than $20 \mathrm{~m}$, are often unable to distinguish between uniform and random patterns. This also occurs at the location of the $10 \mathrm{~m}$ transect, which affects different distribution patterns based on the calculation of the morisita index.

Table 3 Andaliman distribution patterns in 4 locations.

\begin{tabular}{ccccccccc}
\hline Location & $\mathrm{D}$ & $\mathrm{Id}$ & $\mathrm{Mc}$ & $\mathrm{Mu}$ & $\mathrm{Id}-1$ & $\mathrm{Mu}-1$ & $\mathrm{Ip}$ & Pattern of spread \\
\hline 1 & 1200 & 1.00 & 3.79 & 1.12 & 0 & 0.12 & 0.00 & Random \\
2 & 1200 & 0.82 & 2.70 & 1.17 & -0.18 & 0.12 & -0.77 & Uniform \\
3 & 1400 & 0.95 & 2.83 & 1.31 & -0.06 & 0.31 & -0.09 & Uniform \\
4 & 1300 & 1.02 & 2.75 & 1.03 & 0.02 & 0.03 & 0.364 & Clump \\
\hline
\end{tabular}

Note: $\mathrm{D}=$ Density (ind/ha), Id = Morisita dispersion index, Mc = clump index, $\mathrm{Mu}=$ uniform index, Ip = Standard Morisita Indeks 
These statements are consistent with the different distribution pattern of andaliman in Samosir island caused by the social attraction which is economical value of andaliman is high, therefore farmers try to cultivate andaliman by moving the seedlings from its natural habitat to other places.

\section{Spatial Characteristic of Andaliman Habitat}

Kokutse et al. (2016) in their research states that slope will have cohesion of vegetation roots in different type of soil and young vegetation. Figure 2a shows the response of andaliman presence in the flat slopes $(<$ $1 \%)$ until wavy slopes $(8-15 \%)$. These kinds of slopes define small and medium slopes, medium water supply with tight standing and high cultivation production if the climate condition is good.

BSI value is used to identify empty soil area and open field. Rikimaru et al. (2002) states there are interrelationship between land openness and vegetation, that more dominant the open land, the vegetation found will be lesser, or vice versa. Figure $2 \mathrm{~b}$ shows that BSI value response of andaliman presence are between $-0.32-1$. Chances of andaliman presence tends to decrease when the open land area are larger. Therefore andaliman distributions are on the area with some open land space matching with field and bush type vegetation.

Altitude (DEM) of habitat is significantly effect the vegetation variety, vegetation distribution and temperature. The higher altitude in a territory, temperature will be lower vice versa. Figure $2 \mathrm{c}$ shows the response of andaliman presence are between altitude of 1,356 masl - 1,619 masl, and based on the Junghuhn climate classification, territory with that range of altitude are classified as medium or cool territorial. These are also stated by Hasairin (1994) that andaliman will grow in the altitude above 1,300 masl, with the fertile soil condition.

Vegetation variety in the territory with low rainfall is lower than in the territory with higher rainfall. Rainfall also effect soil humidity. Figure $2 d$ shows the response of andaliman presence on rainfall varibable in range of $849-1.605 \mathrm{~mm} /$ year This rainfall is classified as medium but not on the upper nor lower limit. This result are supported by Rakić et al. (2009) that states andaliman is xerophyte vegetation with the characteristic of xemorphic that is able to adapt in mild, humid and warm temperature, also it can live at the rainfall value of 1,500-2,000 $\mathrm{mm} /$ year. Figure 2 shows the response of andaliman presence regarding the ecology variables.

NDVI is standard method used to measure vegetation green level of a territory. NDVI value near 1 shows the green canopy vegetation is very good, but NDVI value less than 0 shows that no vegetation existed in that territory. The forestry department groups NDVI in 3 categories: (1) rare (vegetation 50\%) with NDVI ranges between -0.1 until 0.31 , (2) medium (vegetation $50-70 \%$ ) with NDVI value ranges between 0.32 until 0.42 , and (3) dense (vegetation $70-100 \%$ ) with NDVI value ranges between $0,43-1$. Figure $2 \mathrm{e}$ shows the response of andaliman presence with the NDVI value ranges between $0.025-0.305$. This indicates that andaliman lives in low density level of vegetation. That value shows that andaliman is available in the closed-soil area such as settlements, paddy fields and shrubs (Febrianti and Sofan 2014).

NDMI is index value that shows water and air humidity around the vegetation area, the higher NDMI value then the higher humidity around the vegetation. High humidity found in the valley or territory that near the water flow or riparian. (Dermawan 2017). Figure $2 \mathrm{f}$ shows andaliman presence in the NDMI value between $0.653-0.773$, and it shows that andaliman needs enough density to live. Table 4 shows ecology variable spatial character value of andaliman.

Ecology often related with multivariate data, therefore PCA is often used to study ecology because it enables to reduce data for representative multivariate phenomenon (Janžekovič and Novak 2012). PCA analysis result of andaliman presence spot in the tested variables shows that there are simplifications of six variables resulting two components are not correlated one to another (no multicollinearity). Cumulative value or initial eigenvalue cumulative from the six variables with the requirement above 1 is $81.1 \%$, this value represent most of the variables. Table 5 shows the eigenvalue dan Tabel 6 for factor loading variables for $\mathrm{PC}_{1}$ and $\mathrm{PC}_{2}$. 


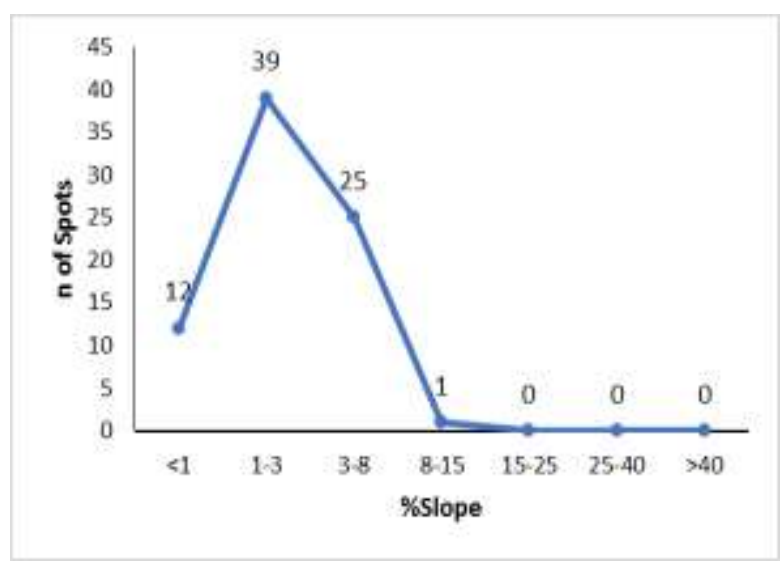

(a)

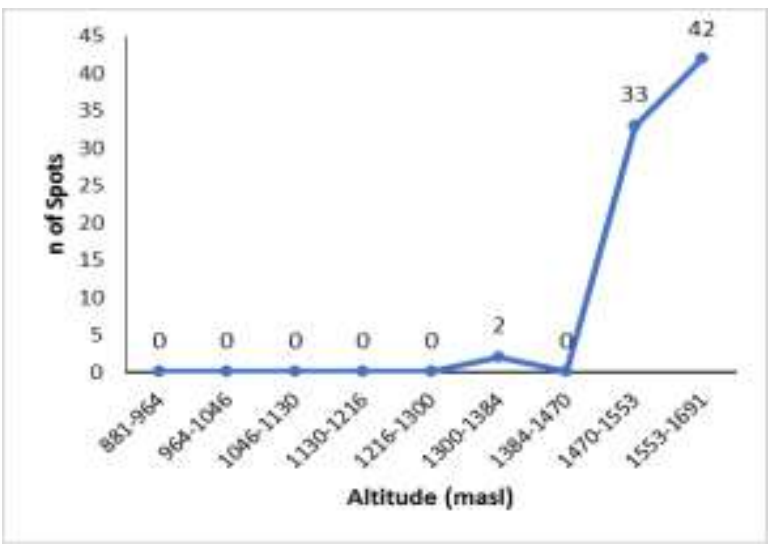

(c)

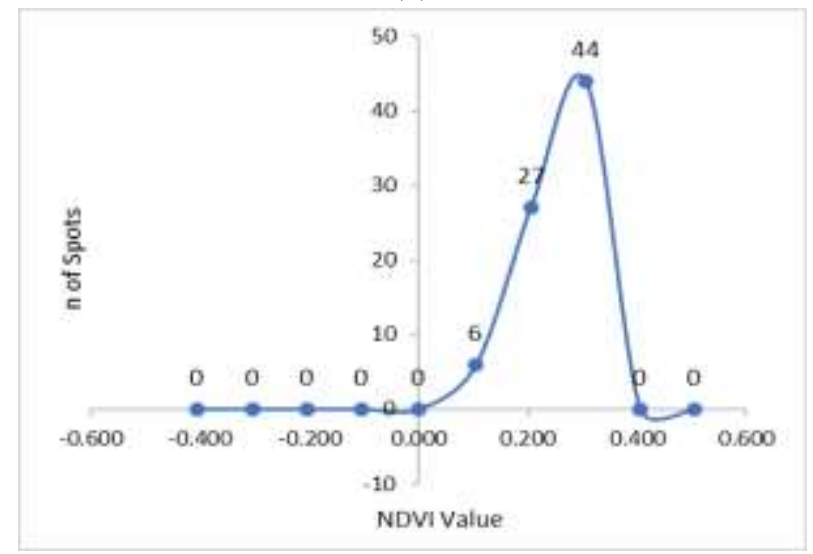

(e)

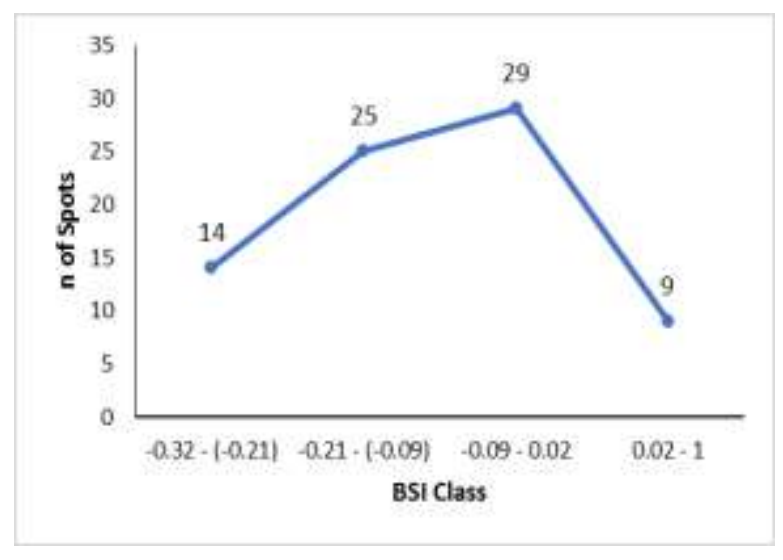

(b)

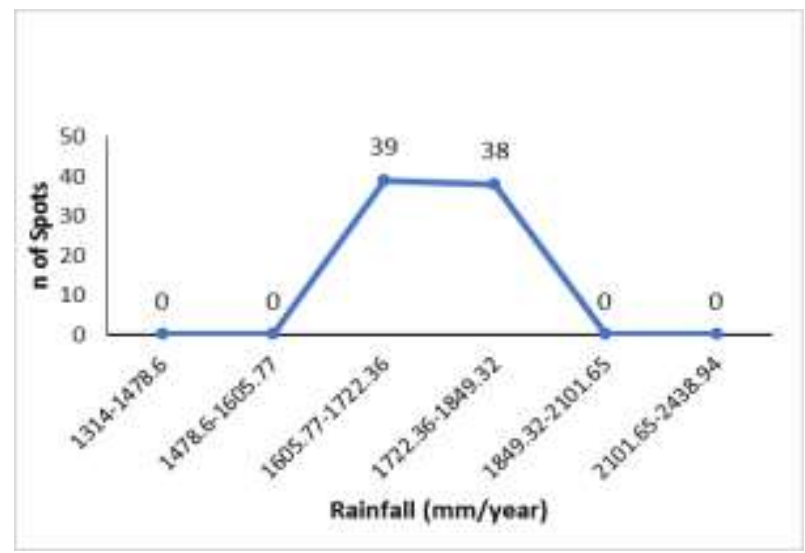

(d)

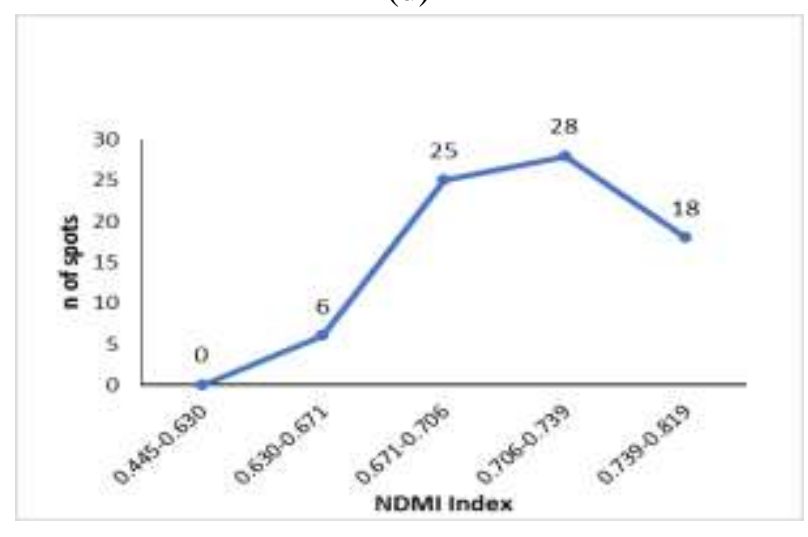

(f)

Figure 2 Andaliman presence spot in (a) slope level, (b) BSI value, (c) altitude level, (d) rainfall, (e) NDVI value and (f) NDMI value.

Table 4 Ecology variable spatial character value.

\begin{tabular}{llll}
\hline \multicolumn{1}{c}{ Variable } & & UoM & \multicolumn{1}{c}{ Value } \\
\hline BSI & - & $-0.32-1$ & \\
NDVI & - & $0.105-0.305$ & \\
NDMI & - & $0.630-0.819$ \\
Slopes & Percent (\%) & $0-68$ \\
DEM & Meter (m) & $1300-1691$ \\
Rainfall & mm/tahun & $1605.7-1849.3$ \\
\hline
\end{tabular}


Table 5 Analysis result of PCA eigenvalues of $\mathrm{PC}_{1}$ and $\mathrm{PC}_{2}$.

\begin{tabular}{rrrr}
\hline Component & \multicolumn{3}{c}{ Initial Eigenvalues } \\
\cline { 2 - 4 } & Total & \% of Variance & Cumulative \% \\
\hline 1 & $\mathbf{3 . 1 8 7}$ & 53.114 & 53.114 \\
2 & $\mathbf{1 . 6 7 9}$ & 27.990 & $\mathbf{8 1 . 1 0 4}$ \\
3 & 0.604 & 10.066 & 91.169 \\
4 & 0.313 & 5.223 & 96.393 \\
5 & 0.214 & 3.561 & 99.953 \\
6 & 0.003 & 0.047 & 100.000 \\
\hline
\end{tabular}

Table 6 Factor loadings values of variables of $\mathrm{PC}_{1}$ dan $\mathrm{PC}_{2}$.

\begin{tabular}{lcc}
\hline & \multicolumn{2}{c}{ PC } \\
\cline { 2 - 3 } Variabel & 1 & 2 \\
\hline BSI & -0.887 & 0.408 \\
NDMI & 0.873 & -0.411 \\
NDVI & 0.845 & -0.241 \\
DEM & 0.606 & 0.655 \\
Slope & 0.722 & 0.532 \\
Rainfall & -0.190 & -0.757 \\
\hline
\end{tabular}

Variance proportion considered enough to represent total data variation if the cumulative variation ranges between $70-80 \%$ (Beaumont 2012). Eigenvalues are value that shows relative weight of each factor in calculating the variance of six analyzed factor. eigenvalue of $\mathrm{PC}_{1}$ is 3.187 with factor loadings $53.11 \%$ (Table 6), while eigenvalue of $\mathrm{PC}_{2}$ is 1.679 with factor loadings $27.9 \%$ (Table 5).

Correlation between variables used in PC can be observed from factor loadings value. Factor loadings value of variables formed the equations as follows:

$\mathrm{PC}_{1}=-0.887(\mathrm{BSI})+0.873(\mathrm{NDMI})+0.845(\mathrm{NDVI})+0.722(\mathrm{DEM})+0.606$ (Rainfall) -0.190 (slope)

$\mathrm{PC}_{2}=-0.757$ (slope) $+0.655($ Rainfall $)+0.532(\mathrm{DEM})-0.411(\mathrm{NDMI})+0.408(\mathrm{BSI})-0.241$ (NDVI)

Eigenvalue in $\mathrm{PC}_{1}$ and $\mathrm{PC}_{2}$ will be considered as weight to estimate data composition from all of the andaliman habitat suitability variables. Andaliman habitat suitability can be calculated through this equation:

$\mathrm{Y}=$ value of andaliman habitat suitability

$$
\mathrm{Y}=3.187\left(\mathrm{PC}_{1}\right)+1.679\left(\mathrm{PC}_{2}\right)
$$

$\mathrm{PC}_{1}=$ First main component

$\mathrm{PC}_{2}=$ Second main component.

Based on validation result from 53 sampling plots of andaliman presence that used to model can be found that 14 sampling plots (25.4\%) in the highly suitable category, 37 sampling plots $(67.3 \%)$ in the suitable category and 2 sampling plots $(0.036 \%)$ in the moderatly suitable category. Proportion of andaliman presence distribution sampling plots describes model accuracy is high $(92.7 \%)$.

\section{Andaliman Habitat Suitability}

The result of andaliman habitat suitability mapping shows that 2.37\% (15 311 ha) area of Samosir island is highly suitable habitat for andaliman. Based on the results of overlapping maps of land use and the results of PCA, the territories are used for plantation forestry. Plantation forestry are restricted government area. Figure 3 shows andaliman distribution in each of andaliman habitat suitability. 
Areal with suitable category found in $36.16 \%$ (233 326 ha) from total area of Samosir island (Figure 3). Andaliman presences are more to be found in this area compared to another suitability class area

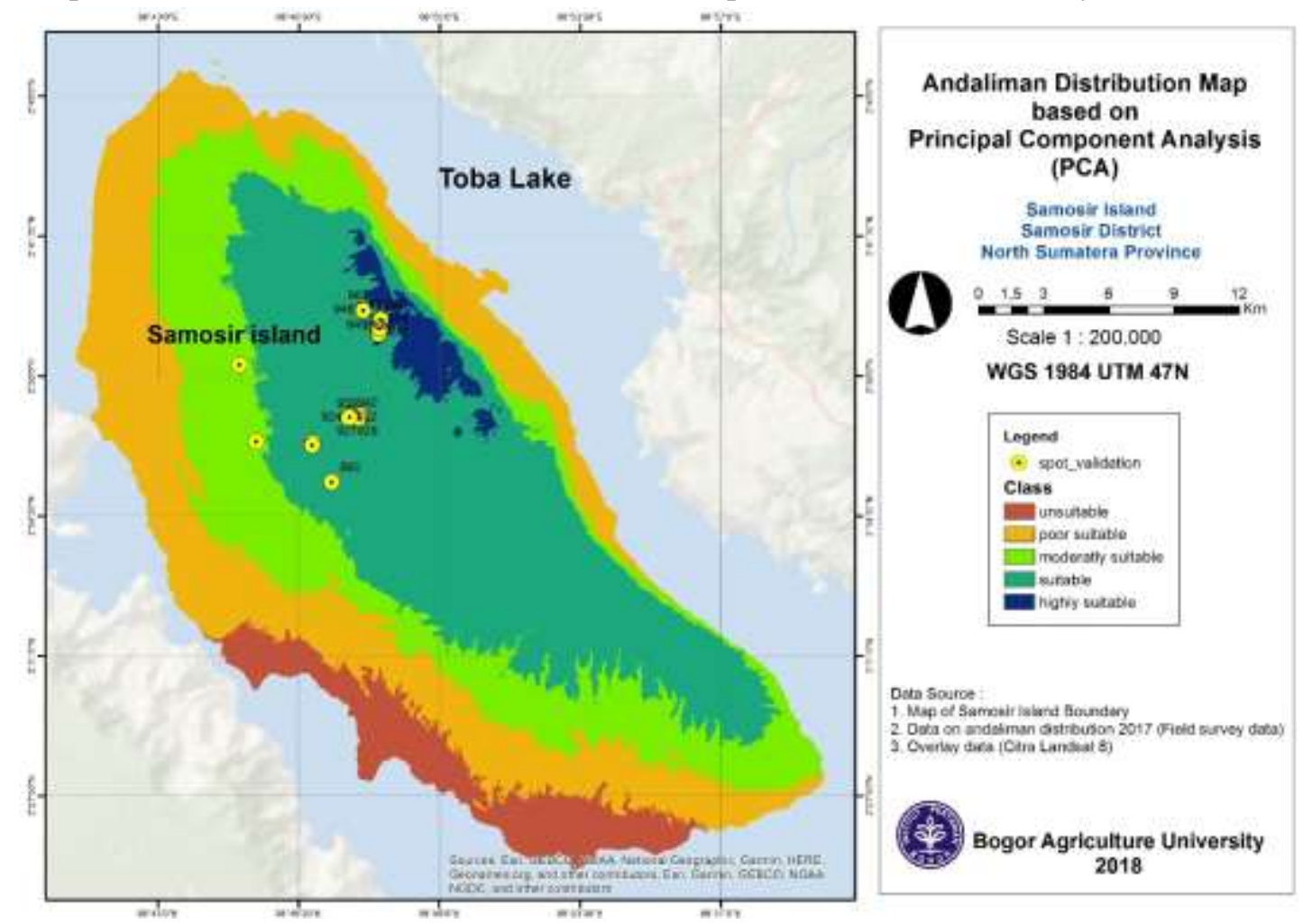

Figure 3 Andaliman distribution map based on PCA result.

Table 7 Class of andaliman habitat suitability based on validation result.

\begin{tabular}{lcclc}
\hline \multicolumn{1}{c}{$\begin{array}{c}\text { Habitat } \\
\text { Suitability }\end{array}$} & $\begin{array}{c}\text { Area } \\
\text { (ha) }\end{array}$ & N of spots & \multicolumn{1}{c}{ Habitat } & Validation (\%) \\
\hline Unsuitable & 50561,1 & - & - & - \\
Poor Suitable & 184784 & - & \multicolumn{1}{c}{ - } & - \\
Moderatly Suitable & 161348 & 2 & $\begin{array}{l}\text { Dryland farming } \\
\text { Plantations forestry, dryland farming, }\end{array}$ & 0.036 \\
Suitable & 233326 & 37 & $\begin{array}{l}\text { paddy fields, open land } \\
\text { Plantations forestry }\end{array}$ & 67.3 \\
Highly suitable & 15311 & 14 & & 25.4 \\
\hline
\end{tabular}

In general this area consists of plantation area, dryland farming and paddy fields, even open land with different soil characteristic (Table 7). This indicates that andaliman habitats are fragmented and potentially will be threat to andaliman continuity. On the other side andaliman habitat fragmentation will be opportunity of andaliman relatively high availability and can be used as priority area to improve quality for andaliman manager for conservation, plant breeding also for andaliman regeneration.

Based on model validation, moderatly suitability of category fit enough for habitat there are $25.00 \%$ (161 348 ha) from total area of Samosir island. Result of interpretation of land usage, all of these territorial are dry land agricultures. With this result, this territory can be used for andaliman conservation, with consideration of altitude factor. Andaliman presence spot in this area is very few which is 2 spots $(0.036 \%)$ (Table 7$)$. 


\section{CONCLUSION}

Andaliman distribution patterns based on the closest distance between individuals vary at each observation location. Location 1 is open land has a standard Morisita index (Ip) of 0.00 which corresponds to a random distribution pattern. Location 2 is plantation forest with Ip $=-0.77$ corresponding to uniform distribution pattern, and location 3 is open field has Ip value $=-0.09$ which corresponds to uniform distribution pattern, while location 4 is area of plantation forest with Ip value $=0.364$ corresponding with a distribution pattern clump.

The most influential variables in the presence of andaliman are land openness factors, followed by NDMI, NDVI, DEM, rainfall and slope. Andaliman likes habitats with rare canopy cover density. Andaliman also shows good adaptability in mild, humid and warm climate, with slopes ranges from mid-flat until wavy in the altitude above 1.300 masl.

Result of andaliman habitat suitability model shows that most of area in Samosir islands (36.16\%) are moderatly suitable habitat for andaliman, with plantation forestry, dryland farming, and paddy fields, whereas areas with highly suitable criteria is $25 \%$ from Samosir island area. This indicates that Samosir islands are potential territory for existence and continuity for andaliman population.

This prediction model of andaliman distribution can be taken into consideration in the effort of habitat management and land suitability of the andaliman population in Samosir island. The necessity test the model with high-resolution imagery, and includes point andaliman absence.

\section{REFERENCES}

Beaumont R. 2012. An introduction to Principal Component Analysis \& Factor Analysis Using SPSS 19 and

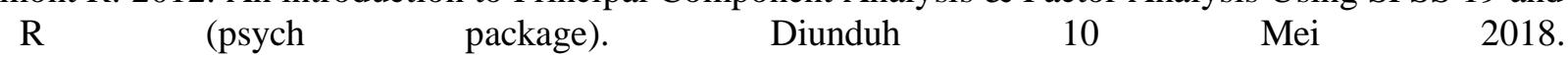
http://www.floppybunny.org/robin/web/virtualclassroom/stats/statistics2/pca1.pdf.

Bleher B, Oberrath R, Böhning-Gaese K. 2002. Seed dispersal, breeding system, tree density and the spatial pattern of trees - a simulation approach. Basic Appl. Ecol. 3:115-123.

Dermawan BA. 2017. Prediksi Sebaran Invasif Spesies Acacia nilotica Dengan Model Maximum Entropy (Studi Kasus Taman Nasional Baluran). [tesis]. Bogor: Sekolah Pascasarjana, Institut Pertanian.

Febrianti N, Sofan P. 2014. Ruang terbuka hijau di DKI Jakarta berdasarkan analisis spasial dan spektral data Landsat 8. Bidang Lingkungan dan Mitigasi Bencana. LAPAN: Pusfatja.

Hartley TG. 1966. A revision of the Malesian species of Zanthoxylum (Rutaceae). J. Arnold Arboretum. 47:171-221.

Hasairin A. 1994. Etnobotani Tumbuhan Rempah dalam Makanan Adat Masyarakat Batak Angkola dan Mandailing [tesis]. Bogor: Program Pascasarjana IPB.

Hasan. 2012. Pemodelan Spasial Sebaran dan Kesesuaian Habitat Spesies Tumbuhan Asing Invasif Kirinyuh (Austroeupatorium inulifolium (Kunth) R. M. King \& H. Rob) di Resort Mandalawangi Taman Nasional Gunung Gede Pangrango. [tesis]. Bogor: Sekolah Pascasarjana, Institut Pertanian Bogor.

Jongjitvimol T, Boontawon K, Wattanachaiyingcharoen W, Deowanish S. 2005. Nest Dispersion of a Stingless Bee Species, Trigona Collina Smith, 1857 (Apidae, Meliponinae) In A Mixed Deciduous Forest in Thailand. The Natural History Journal of Chulalongkorn University. 5(2): 69-71.

Kokilavani V, Narayanan A. 2018. Zanthoxylum acanthopodium DC.. [online] India Biodiversity Portal, Species Page 3: Zanthoxylum acanthopodium. Davailable at: https://indiabiodiversity.org/biodiv/species/show/280529 [Accessed date Sep 4, 2018].

Kokutse NK, Temgoua AGT, Kavazovic' Z. 2016. Slope stability and vegetation: Conceptual and numerical investigation of mechanical effects. Ecological Engineering. 86:146-153. http://dx.doi.org/10.1016/j.ecoleng.2015.11.005.

Leps J, Kindlmann P. 1987. Models of the development of spatial pattern of an even-aged plant population over time. Ecol. Modelling. 39: 45-57. 
Odum EP. 1993. Dasar-Dasar Ekologi. Tj. Samigan. penerjemah; Srigandono, editor. Yogyakarta: Gajah Mada Press. Terjemahan dari: Fundamental of Ecology Ed ke-3.

Rakić T, Šinžar-Sekulić J, Filipović B, Tadić V, Stevanović B, Tan K. 2009. Ecophysiological and Anatomical Characteristics of the Subtropical Shrub Zanthoxylum acanthopodium (Rutaceae) in Conditions of a Temperate Continental Climate (Serbia). Arch. Biol. Sci. Belgrade 61(2): 249-260. DOI:10.2298/ABS0901249R.

Rikimaru A, Roy PS, Miyatake S. 2002. Tropical forest cover density mapping. Trop. Ecology. 43: 39-47.

Soerianegara I, Indrawan A. 2008. Ekologi Hutan Indonesia. Laboratorium Ekologi Hutan. Bogor : Institut Pertanian Bogor.

Suzuki RO, Jun-Ichirou S, Kachi N. 2005. Change in Spatial Distribution Patterns of a Biennial Plant between Growth Stages and Generations in a Patchy Habitat. Annals of Botany. 96: 1009-1017. doi:10.1093/aob/mci253.

Syartinilia dan Tsuyuki S. 2008. GIS-based modeling of Javan Hawk-Eagle distribution using logistic and autologistic regression models. Biological Conservation. 141: 756-769.

Tensiska. 2001. Aktivitas antioksidan ekstrak buah andaliman dalam beberapa sistem pangan dan kestabilan aktivitasnya terhadap kondisi suhu dan $\mathrm{pH}$ [tesis]. Bogor: Sekolah Pascasarjana, Institut Pertanian Bogor.

Wijaya CH. 1999. Andaliman, rempah tradisional Sumatera Utara dengan Antioksidan dan Antimikroba. Teknologi dan Industri Pangan. 2(10): 59-61.

Yonzone R S, Rai. 2016. Zanthoxylum Acanthopodium DC. (Rutaceae) - a favourable ethnomedicinal fruit for the local inhabitants of Darjeeling Himalaya of West Bengal, India. J Complement Med Alt Healthcare. 1(1): 555554. 